Bull. Chem. Soc. Ethiop. 2012, 26(1), 27-42.

Printed in Ethiopia

DOI: http://dx.doi.org/10.4314/bcse.v26i1.4

ISSN 1011-3924

(c) 2012 Chemical Society of Ethiopia

\title{
CONCENTRATION LEVELS OF MAJOR AND TRACE METALS IN ONION (ALLIUM CEPA L.) AND IRRIGATION WATER AROUND MEKI TOWN AND LAKE ZIWAY, ETHIOPIA
}

Reta Birhanu Kitata and Bhagwan Singh Chandravanshi ${ }^{*}$

Department of Chemistry, Addis Ababa University, P.O. Box 1176, Addis Ababa, Ethiopia

(Received September 13, 2011; revised December 18, 2011)

\begin{abstract}
The levels of major ( $\mathrm{Na}, \mathrm{K}, \mathrm{Ca}$ and $\mathrm{Mg}$ ), trace $(\mathrm{Cu}, \mathrm{Co}, \mathrm{Cr}, \mathrm{Mn}$, and $\mathrm{Zn})$, and toxic $(\mathrm{Cd}$ and $\mathrm{Pb})$ metals in onion (Allium cepa L.) bulbs and irrigation water were determined by flame atomic absorption spectroscopy (FAAS). Dissolution of onion samples was carried out by wet digestion with a total volume of $2 \mathrm{~mL}$ $\mathrm{HNO}_{3}(69-72 \%)$ and $2 \mathrm{~mL} \mathrm{HClO}_{4}(70 \%)$ mixture in a flask fitted with reflux condenser on Kjeldahl heating apparatus. The levels of major metals were $\mathrm{Na}(208$ and $121 \mu \mathrm{g} / \mathrm{g}), \mathrm{K}(3127$ and $3298 \mu \mathrm{g} / \mathrm{g}), \mathrm{Ca}(599$ and 550 $\mu \mathrm{g} / \mathrm{g})$ and $\mathrm{Mg}(516$ and $407 \mu \mathrm{g} / \mathrm{g}$ ) in onion irrigated with water from well and Lake Ziway, respectively. Among the trace metals ( $\mu \mathrm{g} / \mathrm{g}$ dry weight), $\mathrm{Zn}$ was the highest (18 and 14) followed by $\mathrm{Mn}$ (8.8 and 13), $\mathrm{Cr}$ (4.9 and 6.6), $\mathrm{Cu}$ (3.2 and 3.6), and $\mathrm{Co}$ (1.2 and 1.8) in onion irrigated with water from well and Lake Ziway, respectively. The toxic metal $\mathrm{Cd}$ was 0.6 and $0.5 \mu \mathrm{g} / \mathrm{g}$ in onion irrigated with well and lake waters, respectively, while $\mathrm{Pb}$ was below method detection limit. The levels of $\mathrm{Na}, \mathrm{K}, \mathrm{Ca}$ and $\mathrm{Mg}$ detected in well water and the Lake Ziway water used for irrigation were $(9.4,4.6 \mathrm{mg} / \mathrm{L}),(43,13 \mathrm{mg} / \mathrm{L}),(23,10 \mathrm{mg} / \mathrm{L})$ and $(30,8.6 \mathrm{mg} / \mathrm{L})$, respectively. Higher levels of $\mathrm{Zn}(0.08 \mathrm{mg} / \mathrm{L})$ and $\mathrm{Co}(0.06 \mathrm{mg} / \mathrm{L})$ were found in the lake water while higher $\mathrm{Mn}(1.1 \mathrm{mg} / \mathrm{L})$ and $\mathrm{Cr}$ $(0.44 \mathrm{mg} / \mathrm{L})$ in well water. The toxic metal $\mathrm{Pb}$ in both well and Lake Ziway water, and $\mathrm{Cd}$ in well water samples were below the method detection limits. $\mathrm{Mn}$ in well water and $\mathrm{Cr}$ in both water samples exceeded the FAO limit of maximum recommended level in irrigation waters.
\end{abstract}

KEY WORDS: Onion (Allium cepa L.), Metals, Irrigation water, Well water, Lake Ziway, Ethiopia

\section{INTRODUCTION}

Vegetables, along with fruits, are considered as "protective supplementary food" as they contain significant quantities of minerals, vitamins, carbohydrates, essential amino acids and dietary fibers required for normal functioning of human metabolic processes and so should be consumed throughout ones entire life. Vegetables are also known to offer the most rapid and low cost source of trace elements for the majority of people in developing nations $[1,2]$.

Allium vegetables are bulbous plants commonly identified by their characteristics onion or garlic taste and pungent odor imparted to them by their content of flavonols and organosulfur compounds [3]. Allium genus has over 500 members, each differing in color, shapes, sizes and tastes of their bulb, but with similar biochemical, phytochemical and neutraceutical content. Most commonly recognized members of the genus include onions (A. cepa), shallots $(A$. oschaninii), leeks (A. ampeloprasum var. porrum), and herbs like garlic (A. sativum) and chives (A. schoenoprasum).

Agricultural sample survey estimated that, in Ethiopia about 18,013 ha of land was covered by allium plants and about 1.76 million tons were produced with an average output of 9.7 tons $\mathrm{ha}^{-1}$ across the country in "Meher" season, September to December, of 2007/08 cropping year [4]. Shallot (A. ascalonicum) is among highly used allium in Ethiopia with sufficient genetic variability [5] but due to the poor yield and difficulty in breeding many cultivars have shifted to onion [6].

*Corresponding author. E-mail: bhagnan@chem.aau.edu.et, bscv2006@yahoo.com 
Onions are one of the common vegetables used as seasonings in tremendous range of dishes, like stews, soups, tomato sauces, cooked vegetables and meat by slicing, chopping, dicing or grating. Onion is also considered part of a group of "functional foods", which offer a particular health benefit over the traditional nutrients they contain. Besides being one of the main condiments, onions are used as a household remedy for a long time as it promotes digestion, cure mild burns and asthma and several other diseases [7].

Soil is an environmental and biochemical reaction system comprising of three important phases: solid (i.e. mineral particles, organic debris, plant roots), solution (i.e. groundwater, rain water, biological excreta, products of biochemical reactions), and gas (i.e. atmospheric, products of biochemical reactions) which move towards equilibrium with one another. Agricultural soil is the most important sink for heavy metals due to soils' high metal retention capacities [8].

Lack of self purification, occurrence of eutrophication, the complex and fragile ecosystem make stagnant lake water more susceptible to pollutants than flowing water [9]. Wastes from house hold, polluted streams, and refuse industrial disposal sites pollute underground water [10]. Underground salt intrusion to coastal lands cause accumulation of excess salt in soil which interferes with osmotic process and metabolisms [11].

All living organisms store and transport metals so as to get appropriate concentration for later uses in physiological reactions as well as a means of protection against the toxic effects of the metals. Growth media including soil, nutrient solution, water and air are main sources of heavy metals to vegetables and other crops, which enter through roots or foliage via two main bio-sorption mechanisms (adsorption and/or absorption) and accumulated in their tissues [12, 13]. Plants capable of taking large quantities of trace metals and storing from the environment are said to be hyper-accumulators [14]. Metal uptake by plants can be affected by several factors including metal concentrations in soils, soil $\mathrm{pH}$, cation exchange capacity, organic matter content, types and varieties of plants, and age of the plant $[9,15]$.

Mineral elements play critical role in building body tissue and regulating numerous physiological processes. They are thus essential constituents of enzymes and hormones; regulate a variety of physiological processes (e.g. osmotic pressure maintenance, oxygen transport, muscle contraction, and central nervous system integrity), and are required for the growth and maintenance of tissues and bones. They are so potent and so important that without them the organism would not be able to use the other remaining constituents of food [16].

Metals in water and food have been a major preoccupation for many years because of their toxicity towards aquatic life, human beings and the environment. The determination of metal content of onion and other vegetables across different parts of the globe were conducted from viewpoints: health risk assessment, nutrient content analysis for consumers, to trace geographic origin of food products, nutritional status assessment of growing plants and assay of suitability of soil and water for farming and as bio-indication for monitoring of environmental pollution.

Assessment of levels of trace metals in onion and other vegetables has been conducted in various countries, e.g., Nigeria [1, 13, 17, 18], China [19], Chile [20], Pakistan [21], UAE [22], Korea [15] and Spain [23]. However, such studies are lacking in Ethiopia. Hence it was worthwhile to determine the levels of major, trace and toxic metals in onion bulbs cultivated in Ethiopia. The objectives of this research were to determine the level of major, trace and toxic metals $(\mathrm{Na}, \mathrm{K}, \mathrm{Ca}, \mathrm{Mg}, \mathrm{Cu}, \mathrm{Co}, \mathrm{Cr}, \mathrm{Mn}, \mathrm{Zn}, \mathrm{Cd}$, and $\mathrm{Pb}$ ) in onion bulbs and irrigation water from well and Lake Ziway used around Meki Town, Ethiopia. The levels of metals in onion were also compared with the irrigation waters and those reported in the literature. 


\section{EXPERIMENTAL}

\section{Apparatus and instrument}

Chopping board (PTFE, China) and Teflon (PTFE) knife were used to cut onion bulbs in to pieces while air-circulating oven (Digitheat, J.P. Selecta, Spain) was used for drying the bulb. Porcelain mortar, pestle and crucibles (Haldenwanger, Germany) were used during pounding of the onion bulb. Analytical balance (Larko, LA114, $110 \mathrm{~g} / 0.1 \mathrm{~g}$, USA) with precision of \pm 0.0001 was used to weigh the onion bulb sample. Round bottom flasks with ground glass joint (100 $\mathrm{mL}$ ) fitted with reflux condenser were used for digesting the onion bulb sample on Kjeldahl heating apparatus (Gallenkamp, England). Borosilicate volumetric flasks $(25,50$ and $100 \mathrm{~mL}$ ) were used during dilution of sample and preparation of metal standard solutions. Measuring cylinders (Duran, Germany), pipettes (Pyrex, USA), and micropipettes (Dragonmed, 1-10 $\mu \mathrm{L}$, 100-1000 $\mu \mathrm{L}$, Shanghai, China) were made use during measuring different quantities of volumes of sample solution, acid reagents and metal standard solutions. Metals' concentration determination was done by flame atomic absorption spectrophotometer (FAAS) (Buck Scientific, Model 210VGP AAS, East Norwalk, USA) that used air-acetylene as fuel-oxidant mixture and that was equipped with deuterium background corrector and hollow cathode lamps.

\section{Chemicals and reagents}

All the reagents and chemicals used in this study were analytical grade. $69-72 \% \mathrm{HNO}_{3}$ and $70 \%$ $\mathrm{HClO}_{4}$ both were purchased from Research-lab Fine Chem Industries, Mumbai, India. Extra pure $30 \% \quad \mathrm{H}_{2} \mathrm{O}_{2}$ (Scharlau, European Union) was used during optimization procedure. Lanthanum chloride hydrate, $99.9 \%$ (Aldrich, USA) was used to prevent the chemical interference on $\mathrm{Ca}$ and $\mathrm{Mg}$ during the analysis of onion bulb and irrigation water samples. Stock standard solution of concentration $1000 \mathrm{mg} / \mathrm{L}$ in $2 \% \mathrm{HNO}_{3}$ of the metals $\mathrm{Na}, \mathrm{K}, \mathrm{Ca}, \mathrm{Mg}, \mathrm{Mn}$, $\mathrm{Cu}, \mathrm{Zn}, \mathrm{Co}, \mathrm{Cr}, \mathrm{Pb}$ and $\mathrm{Cd}$ (Buck Scientific Puro-Graphic, USA) standard solutions were used to prepare intermediate standard solutions. Distilled and deionized water (chemically pure with specific resistance of $18.0 \mathrm{M} \Omega / \mathrm{cm}$ at the working environment) was used for dilution of sample and intermediate metal standard solutions as well as for rinsing glassware and sample bottles.

\section{Study area}

The study area is located between Meki Town and northern part of Lake Ziway (about $8^{0} 09^{\prime} \mathrm{N}$ and $38^{\circ} 45^{\prime} \mathrm{E}$ and about $140 \mathrm{~km}$ south from the capital city, Addis Ababa). There were four main reasons for selecting the study area: (i) the area is under continuous cultivation throughout the year and has been supplying significant portion of a wide variety of vegetables like tomato, onion, cabbage, green pepper, etc to the capital city and local people consumption since long time; (ii) modern farming practices such as mechanized farming, application of agrochemicals (fertilizers, pesticide, insecticides, fungicides, preservative, etc), and selected seeds are significant agricultural inputs used for getting better yield in the area; (iii) the study area is located in the region of the Great Rift Valley known to encompass various lakes and water bodies with poor drainage enhancing different minerals and salt deposits. Lake Ziway is also drainage for two rivers from North Meki River which crosses Meki Town and Katar River from south east direction. Besides, Awash River, which is most used for irrigation in the country, and Mojo River which is close to industrial zone are too close to the study area; (iv) onion plant with emphasis on irrigation water was concern of the study because roots of onion are so shallow that; frequent and deep irrigation with water is required so as to keep the soil moisture 
level high. The large and frequent application of water might increase salt and mineral build-up in soil after evaporation.

The irrigation system practiced in the area is the most common type furrow surface irrigation where waters are distributed through furrows, with crops planted on the ridge between furrows. The waters are pumped out of ground bore well or Lake Ziway, Meki River and others using engine powered water pump.

\section{Irrigation water sampling and pre-treatment}

Ground water and Lake Ziway water irrigating onion farmlands during dry season farming (December to March) in the area were sampled in two rounds. The first was in the period February 19-21, 2009 during early growth of established onion plant while the second round sampling was carried out on March 29 and 30, 2009 during late bulb formation time. Six plots of land (1-4 ha size, each), three plots irrigated with well water and three plots irrigated with Lake Ziway water were selected for the study on the basis of distance from the lake and Meki Town, size of the land, age of the plant during the study time. The local names of the places were Gemo, Derara, Shubi, Walda, Bakile and Giraba.

High density polyethylene (HDPE) bottles with screw cups, which were pre-cleaned, dried and rinsed with the sample water were used to collect the water samples. The well water samples drawn through polyethylene (PE) or polyvinyl chloride (PVC) pipes and irrigation water diverted from Lake Ziway water in an open channel were collected before entering into the farm plots. The sampling was done during two consecutive days. From each of the six sites, about half of the bottles $(1000 \mathrm{~mL})$ were filled over $5 \mathrm{~min}$ from the pipes during the first day while the rest filled the next day in a similar manner. The collected water samples were immediately transported to the laboratory. A $500 \mathrm{~mL}$ portion of well and lake waters, each filtered and acidified with $2 \%(\mathrm{v} / \mathrm{v})$ nitric acid was preserved, without freezing, at about $4{ }^{\circ} \mathrm{C}$ in a refrigerator. The second round sampling was carried out in a similar manner except that 500 $\mathrm{mL}$ bottles were collected from the six sites for $3 \mathrm{~min}$ in each case. Therefore a total of $1000 \mathrm{~mL}$ composite sample of well and lake waters was prepared by combining three-well and three-lake waters, respectively and kept for analysis.

\section{Onion bulb sampling and pre-treatment}

Recently matured ten onion bulb samples which appeared healthy were freshly collected by pulling out by hand from each of the six farm sites where the irrigation waters were collected. The points selected were in such a way that from each division of the plot prepared for irrigation suitability centers and corners were involved. The bulb samples were put in clean plastic bags labelled according to the water samples and brought to the laboratory for further pretreatment.

The roots and remaining leaf parts of the onion bulbs (edible portion corresponding to modified leave or cataphyll) were separated with Teflon knifes, washed with a running tap water so as to remove adsorbed soil particulates and then rinsed with distilled-deionized water and air dried. Peeling the outer dry skin, the bulbs were cut in to nearly equal size to facilitate uniformly drying. About $250 \mathrm{~g}$ of the sliced bulbs were put on acid-washed crucibles labelled according to the sample and dried in air oven at $80{ }^{\circ} \mathrm{C}$ for $48 \mathrm{~h}$ till it got brittle and crisp. Cooling to ambient temperature, the dried samples were pound in to fine powder with porcelain mortar and pestle and sieved with $0.5 \mathrm{~mm}$ sieve. The powdered sample was then placed in pre-cleaned screw capped polyethylene container and stored in desiccators containing calcium chloride to keep to constant dry weight till digestion. 


\section{Wet digestion of onion bulbs}

Several digestion procedures have been described in the literature for digestion of onion bulb samples using mixtures of different proportions of strong oxidizing agents $\mathrm{HNO}_{3}, \mathrm{H}_{2} \mathrm{SO}_{4}$ and $\mathrm{H}_{2} \mathrm{O}_{2}$ [1] or $\mathrm{HNO}_{3}, \mathrm{HClO}_{4}$ and $\mathrm{HCl}$ [21] and considering the strength and amount of oxidizing reagents, time, temperature, simplicity, and safety. In this study digestion of onion bulb samples was performed by optimizing the procedure using different proportions of nitric and perchloric acids at different temperatures and time durations.

A weighed amount $(0.5 \mathrm{~g})$ of dried onion bulb powder was transferred to a round bottom flask $(100 \mathrm{~mL})$ to which $1.5 \mathrm{~mL} \mathrm{HNO}_{3}(69-72 \%)$ and $0.5 \mathrm{~mL} \mathrm{HClO}_{4}(70 \%)$ were added. The mixture was then heated on Kjeldahl heating apparatus fitting the flask to a reflux condenser for $45 \mathrm{~min}$ by setting the temperature to dial $4\left(120^{\circ} \mathrm{C}\right)$ for $25 \mathrm{~min}$, and followed by setting at dial 5 $\left(150{ }^{\circ} \mathrm{C}\right)$ and $6\left(180{ }^{\circ} \mathrm{C}\right)$ each for $10 \mathrm{~min}$. Cooling the mixture, $0.5 \mathrm{~mL}$ of the $\mathrm{HNO}_{3}(69-72 \%)$ and $1.5 \mathrm{~mL} \mathrm{HClO}_{4}(70 \%)$ were added and digestion was continued heating at $150{ }^{\circ} \mathrm{C}$ for $15 \mathrm{~min}$, $180{ }^{\circ} \mathrm{C}$ for $30 \mathrm{~min}, 210{ }^{\circ} \mathrm{C}$ for $30 \mathrm{~min}$ and finally at $270{ }^{\circ} \mathrm{C}$ for $20 \mathrm{~min}$ till the solution became colorless not allowing the solution to dry.

The digest was allowed to cool to room temperature for 10 min without dismantling the condenser and further $10 \mathrm{~min}$ after removing the condenser and then $20 \mathrm{~mL}$ distilled-deionized water was added and filtered into $50 \mathrm{~mL}$ volumetric flask to remove any suspended or turbid matter. Three $5 \mathrm{~mL}$ portions of distilled-deionized water were used to rinse the round bottom flask for the remaining digest. The solution was diluted to mark with distilled-deionized water and mixed thoroughly by shaking after addition of $1 \%$ 'matrix modifier' lanthanum chloride so as to liberate calcium in case phosphate exists in the sample and increase volatilization of matrix [24]. The digestion was carried out in triplicate. Appropriate six blank solutions (containing 1.5 $\mathrm{mL} \mathrm{HNO}_{3}(69-72 \%)$ and $0.5 \mathrm{~mL} \mathrm{HClO}_{4}(70 \%)$ at the beginning and additional $0.5 \mathrm{~mL}$ of the $\mathrm{HNO}_{3}(69-72 \%)$ and $1.5 \mathrm{~mL} \mathrm{HClO}_{4}(70 \%)$ at later stage) were digested accordingly and stored in refrigerator at $4{ }^{0} \mathrm{C}$ without freezing till analysis time.

Analysis of onion bulb and irrigation water sample solutions for metal levels

Calibration standard solutions were prepared for each metal from an intermediate standard solution of $10 \mathrm{mg} / \mathrm{L}$, which was prepared diluting the $1000 \mathrm{mg} / \mathrm{L}$ stock metal standard solution (Buck Scientific Puro-Graphic, USA) with distilled-deionized water in volumetric flasks. Four appropriate working standard solutions of each of the metals were prepared from the intermediate standard solutions. The metal standards were used to trace an external calibration curve with the FAAS. The operating parameters were optimized according to the manufacturer's guide. Determinations of all metals except $\mathrm{Na}$ and $\mathrm{K}$ were done with flame atomic absorption spectroscopy (FAAS) mode. For $\mathrm{Na}$ and $\mathrm{K}$ however the flame atomic emission spectroscopy (FAES) mode was utilized.

\section{Method validation}

The accuracy of digestion procedure and efficiency of the FAAS instrument were checked by spiking sample with known concentration of the analyte. Spiked samples were prepared by adding a small known quantity of metal standard solutions to three sub-samples of onion bulb sample and three sub-samples of one irrigation water sample by applying similar digestion procedure and analyzing for the levels of metals and calculating the recovery percent. For the onion bulb samples equal amounts of reagent acids were added and the optimized procedure was used to digest the blank $(n=6)$ while for water samples, reagent blank samples $(n=6)$ were prepared adding $1 \mathrm{~mL} \mathrm{HNO}_{3}(69-72 \%)$ to volumetric flask $(50 \mathrm{~mL})$ and diluted to the mark by distilled-deionized water. The procedure followed in the spiking of both onion bulb and irrigation water was described below. 
Spiking of onion bulb sample

Three sub-samples of onion bulb powder, each weighing $0.5 \mathrm{~g}$ were transferred to round bottom flasks $(100 \mathrm{~mL})$. Known concentrations of the metal standard solutions were added to each of the three flasks using a micropipette: $300 \mu \mathrm{L}$ of $1000 \mathrm{mg} / \mathrm{L} \mathrm{K}, 30 \mu \mathrm{L}$ of $1000 \mathrm{mg} / \mathrm{L} \mathrm{Na}, 100 \mu \mathrm{L}$ each of $1000 \mathrm{mg} / \mathrm{L} \mathrm{Ca}$ and $\mathrm{Mg}, 350 \mu \mathrm{L}$ of $10 \mathrm{mg} / \mathrm{L} \mathrm{Zn}, 100 \mu \mathrm{L}$ of $10 \mathrm{mg} / \mathrm{L} \mathrm{Mn}, 100 \mu \mathrm{L}$ of 10 $\mathrm{mg} / \mathrm{L} \mathrm{Cr}, 10 \mu \mathrm{L}$ of $10 \mathrm{mg} / \mathrm{L} \mathrm{Cd}, 50 \mu \mathrm{L}$ of $10 \mathrm{mg} / \mathrm{L} \mathrm{Pb}$ and $120 \mu \mathrm{L}$ of $5 \mathrm{mg} / \mathrm{L} \mathrm{Cu}$ solutions. The spiked samples were digested using the optimized procedure for the onion bulb sample and finally analyzed using FAAS/FAES to calculate the percent recoveries.

\section{Spiking of irrigation water samples}

Three sub-samples of irrigation water from well, $40 \mathrm{~mL}$ each were taken in $50 \mathrm{~mL}$ volumetric flasks and to each, known volume and concentrations of metal standards added: $425 \mu \mathrm{g}$ of $\mathrm{K}$, $156.25 \mu \mathrm{g}$ of $\mathrm{Na}, 275 \mu \mathrm{g}$ of $\mathrm{Ca}, 375 \mu \mathrm{g}$ of $\mathrm{Mg}, 0.75 \mu \mathrm{g}$ of $\mathrm{Zn}, 12.5 \mu \mathrm{g}$ of $\mathrm{Mn}, 6.88 \mu \mathrm{g}$ of $\mathrm{Cr}$, $0.10 \mu \mathrm{g}$ of $\mathrm{Cu}, 0.05 \mu \mathrm{g}$ of $\mathrm{Co}$ and the flask was filled to the mark by the water sample. Cd and $\mathrm{Pb}$ were spiked in lake water samples separately by adding $0.02 \mu \mathrm{g}$ of $\mathrm{Cd}$ and $0.10 \mu \mathrm{g}$ of $\mathrm{Pb}$ in $50 \mathrm{~mL}$ volumetric flask water. The spiked samples were run on FAAS/FAES for metals content determinations to calculate the percent recoveries.

\section{Method detection limit}

For estimating the method detection limits, reagent blank solutions $(n=6)$ with equal volume to that added in the onion bulb sample were digested following the same procedures. For irrigation water samples reagent blanks $(\mathrm{n}=6)$ were prepared by taking $1 \mathrm{~mL}$ of $\mathrm{HNO}_{3}(69-72 \%)$ in volumetric flaks $(50 \mathrm{~mL})$ and diluted to the mark with distilled-deionized water. The reagent blanks of both onion bulb and irrigation waters were run on FAAS for all metals except $\mathrm{Na}$ and $\mathrm{K}$, for which emission mode (FAES) was used in similar manners the samples for metals concentrations determination so as to calculate standard deviations and estimate method detection limits.

\section{Statistical methods}

Linear regression analysis of calibration curve was used to calculate unknown concentration, sensitivity, correlation coefficients and standard deviation. Average concentration and standard deviations of triplicate measurements were reported for the samples. Variance in sampling and analysis were determined by F-test through one-way ANOVA. Student t-test was calculated to identify whether the means of the concentration between the two onion bulbs and the two irrigation water samples vary significantly by Statistical Package for Social Science (SPSS statistic 15.0 Microsoft window) as well as excel work sheet (Microsoft Office Excel, 2007).

\section{RESULTS AND DISCUSSION}

\section{Figures of merit}

The analytical wavelengths, the correlation coefficients and the correlation equations of the calibration curves for the determination of metals in the samples by FAAS are given in Table 1. The correlation coefficients of all the calibration curves were $>0.999$ and these correlation coefficients showed that there was very good correlation (relationship) between concentration and absorbance. 
Detection limit of an analyte is the smallest quantity (concentration) of analyte which can be detected but not quantified at a given confidence level. Detection limit of certain method may vary greatly often with matrix and experimental procedures [25]. In this study method detection limit for each metal was estimated by digesting six analytical blanks with the optimized procedure for the onion bulb and water samples, respectively. Each blank solution was run with FAAS for the metals level in similar manner as the samples and standard deviations of the blanks' concentration were calculated. The method detection limit for the metal analyte is therefore here the concentration in the sample matrix at which analyte signal equals at least three times that of noise $\left(3 \delta_{\text {blank }}\right.$, where $\delta=$ standard deviation of the blanks, $n=6$ for onion bulb or irrigation water samples (Table 1 ).

Table 1. Analytical wavelengths, detection limits, correlation coefficients and correlation equations of the calibration curves for the determination of metals in onion bulb samples by FAAS.

\begin{tabular}{|c|c|c|c|c|c|}
\hline \multirow{2}{*}{ Metal } & \multirow{2}{*}{$\begin{array}{l}\text { Wavelength } \\
(\mathrm{nm})\end{array}$} & \multicolumn{2}{|c|}{ Method detection limit for } & \multirow{2}{*}{$\begin{array}{l}\text { Correlation } \\
\text { coefficient }\end{array}$} & \multirow{2}{*}{ Calibration equation } \\
\hline & & $\begin{array}{c}\text { onion bulb } \\
\text { (mg/kg dry } \mathrm{wt})\end{array}$ & $\begin{array}{l}\text { irrigation water } \\
(\mathrm{mg} / \mathrm{L})\end{array}$ & & \\
\hline $\mathrm{Na}$ & 589.0 & 0.5 & 0.1 & 0.9992 & $Y=8.709+266.2 X$ \\
\hline $\mathrm{K}$ & 766.5 & 0.5 & 0.2 & 0.9986 & $\mathrm{Y}=2.911+36.31 \mathrm{X}$ \\
\hline $\mathrm{Ca}$ & 422.7 & 0.5 & 0.1 & 0.9999 & $Y=0.0005965+0.06477 X$ \\
\hline $\mathrm{Mg}$ & 285.2 & 0.1 & 0.03 & 0.9999 & $Y=0.006550+0.4822 X$ \\
\hline $\mathrm{Cu}$ & 324.7 & 0.2 & 0.02 & 0.9997 & $\mathrm{Y}=0.002160+0.05810 \mathrm{X}$ \\
\hline Co & 240.7 & 0.1 & 0.01 & 0.9997 & $Y=-0.00007309+0.01614 X$ \\
\hline $\mathrm{Cr}$ & 357.9 & 0.5 & 0.1 & 0.9999 & $\mathrm{Y}=0.0003230+0.1327 \mathrm{X}$ \\
\hline $\mathrm{Mn}$ & 279.5 & 0.4 & 0.002 & 0.9999 & $Y=0.0009624+0.05317 X$ \\
\hline $\mathrm{Zn}$ & 213.9 & 0.1 & 0.01 & 0.9993 & $\mathrm{Y}=0.001070+0.1778 \mathrm{X}$ \\
\hline $\mathrm{Cd}$ & 228.9 & 0.1 & 0.007 & 0.9999 & $\mathrm{Y}=0.0003230+0.1327 \mathrm{X}$ \\
\hline $\mathrm{Pb}$ & 283.2 & 0.5 & 0.1 & 0.9993 & $Y=0.001070+0.1778 X$ \\
\hline
\end{tabular}

The method detection limits estimated were higher for all metals in onion bulb than in irrigation water samples. However the method detection limits were low enough to detect the presence of metal of interest at trace levels in both the onion bulb and irrigation water samples.

The reproducibility of the analytical procedure was checked by carrying out a triplicate analysis and calculating the relative standard deviations for each metal. The \% RSD results did not differ by more than $10 \%$ of the mean which indicated that the analytical method used is precise and reliable.

Table 2. Recovery test results for the metals determination in onion bulb (mean $\pm \mathrm{SD}$ ).

\begin{tabular}{|c|c|c|c|c|}
\hline \multirow{2}{*}{ Metal } & \multicolumn{2}{|c|}{ Concentration $(\mu \mathrm{g} / \mathrm{g})$ in onion bulb } & \multirow{2}{*}{ \% Recovery } \\
\cline { 2 - 4 } & un-spiked sample & spiked amount & spiked sample & \\
\hline $\mathrm{Na}$ & $208 \pm 5$ & 60 & $262 \pm 6$ & $93 \pm 2$ \\
\hline $\mathrm{K}$ & $3127 \pm 40$ & 600 & $3696 \pm 47$ & $95 \pm 1$ \\
\hline $\mathrm{Ca}$ & $599 \pm 30$ & 200 & $803 \pm 40$ & $102 \pm 5$ \\
\hline $\mathrm{Mg}$ & $516 \pm 12$ & 200 & $708 \pm 16$ & $96 \pm 2$ \\
\hline $\mathrm{Cu}$ & $3.21 \pm 0.08$ & 1.2 & $4.33 \pm 0.11$ & $93 \pm 3$ \\
\hline $\mathrm{Co}$ & $1.23 \pm 0.03$ & 0.4 & $1.62 \pm 0.05$ & $98 \pm 3$ \\
\hline $\mathrm{Cr}$ & $4.94 \pm 0.18$ & 2.0 & $6.76 \pm 0.25$ & $91 \pm 4$ \\
\hline $\mathrm{Mn}$ & $8.8 \pm 0.1$ & 2.0 & $10.66 \pm 0.12$ & $93 \pm 1$ \\
\hline $\mathrm{Zn}$ & $18 \pm 0.67$ & 7.0 & $24.65 \pm 1.39$ & $95 \pm 4$ \\
\hline $\mathrm{Cd}$ & $0.64 \pm 0.07$ & 0.2 & $0.82 \pm 0.08$ & $90 \pm 10$ \\
\hline $\mathrm{Pb}$ & $<0.5$ & 1.0 & $1.03 \pm 0.04$ & $103 \pm 4$ \\
\hline
\end{tabular}

Bull. Chem. Soc. Ethiop. 2012, 26(1) 
Table 3. Recovery test results for the metals determination in water (mean $\pm \mathrm{SD}$ ).

\begin{tabular}{|l|c|c|c|c|}
\hline \multirow{2}{*}{ Metal } & \multicolumn{2}{|c|}{ Concentration (mg/L) in irrigation water } & \multirow{2}{*}{ \% Recovery } \\
\cline { 2 - 4 } & un-spiked sample & spiked amount & spiked sample & \% \\
\hline $\mathrm{Na}$ & $9.35 \pm 0.003$ & 3.125 & $12.22 \pm 0.004$ & $92 \pm 4$ \\
\hline $\mathrm{K}$ & $42.6 \pm 0.7$ & 8.5 & $50.61 \pm 0.83$ & $94 \pm 8$ \\
\hline $\mathrm{Ca}$ & $22.6 \pm 0.5$ & 5.5 & $27.88 \pm 0.62$ & $96 \pm 6$ \\
\hline $\mathrm{Mg}$ & $30.1 \pm 1$ & 7.5 & $37.06 \pm 1.23$ & $93 \pm 3$ \\
\hline $\mathrm{Cu}$ & $<0.02$ & 0.10 & $0.106 \pm 0.003$ & $106 \pm 3$ \\
\hline $\mathrm{Co}$ & $<0.01$ & 0.05 & $0.046 \pm 0.003$ & $92 \pm 6$ \\
\hline $\mathrm{Cr}$ & $0.44 \pm 0.01$ & 0.1375 & $0.58 \pm 0.01$ & $102 \pm 4$ \\
\hline $\mathrm{Mn}$ & $1.06 \pm 0.01$ & 0.25 & $1.30 \pm 0.01$ & $96 \pm 6$ \\
\hline $\mathrm{Zn}$ & $0.037 \pm 0.004$ & 0.015 & $0.0515 \pm 0.0056$ & $97 \pm 4$ \\
\hline $\mathrm{Cd}$ & $<0.007$ & 0.002 & $0.0021 \pm 0.0001$ & $105 \pm 7$ \\
\hline $\mathrm{Pb}$ & $<0.1$ & 0.1 & $0.105 \pm 0.004$ & $105 \pm 4$ \\
\hline
\end{tabular}

In this study, the method validation was made by the spiking experiment in which known quantities of the metals standard solution were added to three samples for onion bulb cultivated with well water and applied the whole procedure to the mixture (spiked samples) and calculated the percent recoveries. Recovery experiments were also made on the water samples similarly. The obtained percentage recovery varied from $90 \%$ to $105 \%$ in both the onion bulb and irrigation water samples which were in the acceptable range (Table 2 and 3).

Determination of metals in onion bulb and irrigation water samples

The well water and Lake Ziway water and onion bulbs samples irrigated with each type of water were analyzed for major $(\mathrm{K}, \mathrm{Na}, \mathrm{Ca}, \mathrm{Mg})$, trace essential $(\mathrm{Cu}, \mathrm{Mn}, \mathrm{Zn}, \mathrm{Cr}$ and $\mathrm{Co})$, and trace non-essential metals $(\mathrm{Cd}$ and $\mathrm{Pb})$ with FAAS. The levels of metals along with standard deviation of triplicate analysis are given in Table 4 and 5 for onion bulb and irrigation water, respectively.

Table 4. Average concentration (mean $\pm \mathrm{SD}, \mathrm{n}=3$ in $\mu \mathrm{g} / \mathrm{g}$ dry weight) of metals in onion bulbs.

\begin{tabular}{|l|c|c|}
\hline Metal & $\begin{array}{c}\text { Onion irrigated with well } \\
\text { water }(\mu \mathrm{g} / \mathrm{g} \text { dry weight })\end{array}$ & $\begin{array}{c}\text { Onion irrigated with lake water } \\
(\mu \mathrm{g} / \mathrm{g} \text { dry weight })\end{array}$ \\
\hline $\mathrm{Na}$ & $208 \pm 5$ & $121 \pm 3$ \\
\hline $\mathrm{K}$ & $3127 \pm 40$ & $3298 \pm 54$ \\
\hline $\mathrm{Ca}$ & $599 \pm 30$ & $550 \pm 20$ \\
\hline $\mathrm{Mg}$ & $516 \pm 12$ & $407 \pm 30$ \\
\hline $\mathrm{Cu}$ & $3.2 \pm 0.1$ & $3.6 \pm 0.2$ \\
\hline $\mathrm{Mn}$ & $8.8 \pm 0.2$ & $13 \pm 1$ \\
\hline $\mathrm{Zn}$ & $18 \pm 1$ & $14 \pm 1$ \\
\hline $\mathrm{Co}$ & $1.2 \pm 0.5$ & $1.8 \pm 0.1$ \\
\hline $\mathrm{Cr}$ & $4.9 \pm 0.2$ & $6.6 \pm 0.1$ \\
\hline $\mathrm{Cd}$ & $0.64 \pm 0.07$ & $0.53 \pm 0.06$ \\
\hline $\mathrm{Pb}$ & $<0.5$ & $<0.5$ \\
\hline
\end{tabular}


Table 5. Average concentration (mean $\pm \mathrm{SD}$, in $\mathrm{mg} / \mathrm{L}, \mathrm{n}=3$ ) metals in irrigation waters.

\begin{tabular}{|l|c|c|}
\hline Metal & Well water $(\mathrm{mg} / \mathrm{L})$ & Lake Ziway water $(\mathrm{mg} / \mathrm{L})$ \\
\hline $\mathrm{Na}$ & $9.4 \pm 0.1$ & $4.6 \pm 0.1$ \\
\hline $\mathrm{K}$ & $43 \pm 1$ & $13 \pm 1$ \\
\hline $\mathrm{Ca}$ & $23 \pm 1$ & $10 \pm 0.2$ \\
\hline $\mathrm{Mg}$ & $30 \pm 1$ & $8.6 \pm 0.1$ \\
\hline $\mathrm{Cr}$ & $0.44 \pm 0.01$ & $0.42 \pm 0.02$ \\
\hline $\mathrm{Mn}$ & $1.06 \pm 0.01$ & $0.054 \pm 0.005$ \\
\hline $\mathrm{Zn}$ & $0.037 \pm 0.004$ & $0.084 \pm 0.004$ \\
\hline $\mathrm{Co}$ & $<0.01$ & $0.055 \pm 0.002$ \\
\hline $\mathrm{Cd}$ & $<0.007$ & $0.0062 \pm 0.0004$ \\
\hline $\mathrm{Cu}$ & $<0.02$ & $<0.02$ \\
\hline $\mathrm{Pb}$ & $<0.1$ & $<0.1$ \\
\hline
\end{tabular}

Distribution patterns of metals in the samples

Onion bulb sample analyses for the metals indicated that except $\mathrm{Pb}$ which was below the method detection limit, all the ten metals ( $\mathrm{Na}, \mathrm{K}, \mathrm{Ca}, \mathrm{Mg}, \mathrm{Cu}, \mathrm{Co}, \mathrm{Cr}, \mathrm{Mn}, \mathrm{Zn}, \mathrm{Cd}$ ) were detected (Table 4). The levels of metals, however, differ significantly among each other and slightly between onion bulb irrigated with well and Lake Ziway waters. The trend of variation in both onion bulb samples were $\mathrm{K}>\mathrm{Ca}>\mathrm{Mg}>\mathrm{Na}>\mathrm{Zn}>\mathrm{Mn}>\mathrm{Cr}>\mathrm{Cu}>\mathrm{Co}>\mathrm{Cd}$.

Of the eleven metals included in this study, $\mathrm{Cu}, \mathrm{Co}, \mathrm{Cd}$ and $\mathrm{Pb}$ in well water and $\mathrm{Cu}$ and $\mathrm{Pb}$ in lake water samples were found to be below the method detection limits while the presence of the rest of metals, $\mathrm{K}, \mathrm{Na}, \mathrm{Ca}, \mathrm{Mg}, \mathrm{Cr}, \mathrm{Zn}$, and $\mathrm{Mn}$ in the well water and $\mathrm{K}, \mathrm{Na}, \mathrm{Ca}, \mathrm{Mg}, \mathrm{Cr}, \mathrm{Zn}$, $\mathrm{Mn}, \mathrm{Co}$, and $\mathrm{Cd}$ in the lake water were observed. Metal ion uptake into the roots of plants is extremely complex phenomenon occurring via both diffusion and mass flow of the soil solution. Chelation and surface adsorption, which are $\mathrm{pH}$ dependent, also affect availability of nutrient metal ions. In general acidic soil conditions retard uptake of essential divalent metal ions but increase the availability of $\mathrm{Mn}, \mathrm{Fe}$, and $\mathrm{Al}$, all of which are normally of very limited availability because of hydrolysis of the trivalent ions [26].

\section{Distribution pattern of metals in onion bulb samples}

In onion bulbs only $\mathrm{Pb}$ was found to be below the method detection limit while others were detected. The concentration determined in onion bulbs irrigated with well water were $208 \pm 5$, $3127 \pm 40,599 \pm 30$, and $516 \pm 12 \mu \mathrm{g} / \mathrm{g}$ dry weight for $\mathrm{Na}, \mathrm{K}, \mathrm{Ca}$ and $\mathrm{Mg}$, respectively. While the levels of major metals in the onion bulb irrigated with lake water were $121 \pm 3,3298 \pm 54$, $550 \pm 20$, and $407 \pm 30 \mu \mathrm{g} / \mathrm{g}$ for $\mathrm{Na}, \mathrm{K}, \mathrm{Ca}$ and $\mathrm{Mg}$, respectively.

The levels of trace metals detected in onion bulb irrigated with well and lake water were $3.2 \pm 0.1$ and $3.6 \pm 0.2 \mathrm{Cu}, 8.8 \pm 0.2$ and $13 \pm 1 \mathrm{Mn}, 18 \pm 1$ and $14 \pm 1 \mathrm{Zn}, 1.2 \pm 0.5$ and $1.8 \pm 0.1 \mathrm{Co}$, $4.9 \pm 0.2$ and $6.6 \pm 0.1 \mathrm{Cr}, 0.6 \pm 0.1$ and $0.5 \pm 0.1 \mathrm{Cd} \mu \mathrm{g} / \mathrm{g}$ (Table 4). These results indicated that $\mathrm{Zn}$ was the most accumulated trace metal in the onion bulb sample with higher amount in the onion irrigated with well water. The level of Cd was the least among the metals; however due to its toxicity deserves special concern.

The levels of metals in onion bulb samples irrigated with well and lake waters, though comparable, higher concentration of major metals were determined in onion bulb irrigated with the well water except $\mathrm{K}$ which was slightly higher in onion irrigated with lake water. For most of trace metals the reverse was observed that higher essential trace metals exist in onion irrigated with Lake Ziway water except for $\mathrm{Zn}$ and $\mathrm{Cd}$. 


\section{Distribution pattern of metals in irrigation water samples}

The irrigation water sampled from well and lake at the point of diversion from pipe were also found to contain detectable metals $\mathrm{Na}, \mathrm{K}, \mathrm{Ca}, \mathrm{Mg}, \mathrm{Cr}, \mathrm{Zn}, \mathrm{Mn}$. Co and Cd were also detected in lake water but not in the well water. Besides, $\mathrm{Cu}$ and $\mathrm{Pb}$ were below detection limit in both irrigation water samples. The mean \pm standard deviations obtained were $9.4 \pm 0.1$ and $4.6 \pm 0.1$ $\mathrm{Na}, 43 \pm 2$ and $12.5 \pm 1.0 \mathrm{~K}, 22.7 \pm 0.5$ and $10.0 \pm 0.2 \mathrm{Ca}, 30 \pm 1$ and $8.6 \pm 0.1 \mathrm{mg} / \mathrm{L} \mathrm{Mg}$ in the well and lake water samples, respectively. Higher concentrations of major metals were obtained in the well water samples than that of lake water.

The mean and standard deviations of the levels of trace metals in well water employed for irrigation were $0.44 \pm 0.01,1.1 \pm 0.1$ and $0.04 \pm 0.01, \mathrm{mg} / \mathrm{L}$ for $\mathrm{Cr}, \mathrm{Mn}$ and $\mathrm{Zn}$, respectively. The concentrations of trace metals obtained from this study in irrigation water of Lake Ziway were $0.42 \pm 0.02,0.054 \pm 0.005,0.084 \pm 0.004,0.055 \pm 0.002,0.006 \pm 0.001$, and $\mathrm{mg} / \mathrm{L}$ for $\mathrm{Cr}, \mathrm{Mn}, \mathrm{Zn}$, $\mathrm{Co}$, and $\mathrm{Cd}$, respectively. $\mathrm{Cu}$ and $\mathrm{Pb}$ were below the method detection limit in both the well and lake water samples. Co in well water sample was also below method detection limit (Table 5).

\section{Metal specific distribution patterns}

$\mathrm{K}$ was found in highest concentration among all the metals analyzed in this study with concentration of $3127 \pm 40$ and $3298 \pm 54 \mu \mathrm{g} / \mathrm{g}$ in onion bulbs cultivated with well and lake water, respectively. The respective levels of $K$ in the irrigation water were $43 \pm 2$ and $12.5 \pm 1.0 \mathrm{mg} / \mathrm{L}$ in well and lake water samples, respectively. Although the levels of $\mathrm{K}$ in onion bulb samples were comparable, the difference is higher among the irrigation water samples. $\mathrm{K}$ is an essential nutrient of both plants and animals. It is among the primary macronutrients. The percent of $\mathrm{K}$ in living plant material is about $0.3 \%$ which may reach from $1.5-4 \%$ in the dry plant matter. The level of $\mathrm{K}$ in onion bulbs in this study is within the proportion proposed in plant materials. It might have originated from the mixed fertilizers applied to soil, mineral deposits in soil, and salts in the irrigation water, which was also containing significant amount.

$\mathrm{Na}$ is not known as essential for plants and the quantity accumulated is also usually smaller than that of $\mathrm{K}$. The levels of $\mathrm{Na}$ obtained in this study were $208 \pm 5 \mu \mathrm{g} / \mathrm{g}$ (onion bulb irrigated with well water), $121 \pm 3$ (onion bulb irrigated with lake water), $4.6 \pm 0.1 \mathrm{mg} / \mathrm{L}$ in well water sample and $9.4 \pm 0.1 \mathrm{mg} / \mathrm{L}$ in lake water samples used for irrigation. The level indicated that $\mathrm{Na}$ is least accumulated by onion bulb among the four major metals determined in all the samples.

$\mathrm{Ca}$ was the most accumulated metal after $\mathrm{K}$ in onion bulbs studied with mean concentrations $599 \pm 30$ and $550 \pm 20 \mu \mathrm{g} / \mathrm{g}$ in onion bulbs irrigated with well and lake water samples, respectively; $9.9 \pm 0.1$ and $22.6 \pm 0.5 \mathrm{mg} / \mathrm{L}$ in the agricultural water from well and lake water samples, respectively. Higher level of Ca was observed in well water as well as onion cultivated with the well water than that of lake water which may be in line with the common hardness of ground water expected.

$\mathrm{Mg}$ concentration level in this study were $516 \pm 12$ and $407 \pm 30 \mu \mathrm{g} / \mathrm{g}$ in onion bulbs irrigated with well and lake waters; $30 \pm 1$ and $8.6 \pm 0.1 \mathrm{mg} / \mathrm{L}$ in corresponding well and lake water, respectively. The results revealed that high concentration of $\mathrm{Mg}$ exists in well water and onion irrigated with it as in the case of calcium. In water $\mathrm{Mg}$ contributes to total water hardness which may be the cause for higher concentration in well water and associated onion bulb.

$\mathrm{Cu}$ concentrations in onion bulbs irrigated with well and lake water were $3.2 \pm 0.1$ and $3.6 \pm 0.2 \mu \mathrm{g} / \mathrm{g}$, respectively. However the levels in irrigation waters were below method detection limit. Therefore the principal source of $\mathrm{Cu}$ for onion plant might be the soil or soil contaminants. For human being $1-3 \mathrm{mg} \mathrm{Cu}$ was required each day for normal body function. The bio-availability of $\mathrm{Cu}$ for plants decreases with increase in $\mathrm{pH}$ of soil. $\mathrm{Cu}$ content of normal plant tissues varies according to species but is usually within the range $1-25 \mathrm{mg} / \mathrm{kg}$.

Bull. Chem. Soc. Ethiop. 2012, 26(1) 
The concentration of $\mathrm{Zn}$ obtained in onion bulbs irrigated with well and lake water were $18.0 \pm 0.7$ and $14.1 \pm 0.4 \mu \mathrm{g} / \mathrm{g}$, respectively. The corresponding results for well and Lake Ziway water samples applied to the onion farm were $0.04 \pm 0.00$ and $0.08 \pm 0.00 \mathrm{mg} / \mathrm{L} \mathrm{Zn}$, respectively. $\mathrm{Zn}$ is an essential trace metal involved in growth and DNA synthesis in human with normal daily intake of 7-16 mg per day for adults. The levels of $\mathrm{Zn}$ obtained in edible portion of onion in this study are within the ranges estimated in plants. In the normal daily consumption of onion bulb as condiment, the level of $\mathrm{Zn}$ cannot have negative effect on human.

Mn was the second most accumulated trace metal next to zinc in onion bulb and even the one obtained in highest quantity in irrigation water from well. The levels in onion bulbs irrigated with well and lake water were $8.8 \pm 0.2$ and $13 \pm 1 \mu \mathrm{g} / \mathrm{g}$, respectively and $1.1 \pm 0.1$ and $0.05 \pm 0.005 \mathrm{mg} / \mathrm{L}$ for the respective well and Lake Ziway waters. Perk [27] explained that manganese oxide surface precipitated forms Mn nodules or coat on sediments or rock which when subsurface is in contact with the precipitate may possess concentration up to about 1 $\mathrm{mg} / \mathrm{L}$. He further added acidic ground water may also contain high levels of dissolved $\mathrm{Mn}^{2+}$ ion up to $1 \mathrm{mg} / \mathrm{L}$ which is far higher than the mean level in this study for well water $(0.054 \mathrm{mg} / \mathrm{L})$.

The $\mathrm{Cr}$ content of onion bulbs samples in this study were $4.9 \pm 0.2$ and $6.6 \pm 0.1 \mu \mathrm{g} / \mathrm{g}$ for those irrigated with well water and lake water, respectively. The corresponding values of $\mathrm{Cr}$ in the well and Lake Ziway water were $0.44 \pm 0.01$ and $0.42 \pm 0.02 \mathrm{mg} / \mathrm{L}$, respectively. Compared to trace metals $\mathrm{Cr}$ ranks second in both plant and water samples. Higher levels were obtained in onion bulbs of lake water though the difference is very small for the water used during irrigation. The trivalent chromium, $\mathrm{Cr}(\mathrm{III})$, is essential trace element for adult human being with safe and adequate daily requirement of 50-200 $\mu \mathrm{g}$ and toxic only at high level.

The Co concentrations in onion bulb samples were $1.2 \pm 0.5$ and $1.8 \pm 0.1 \mu \mathrm{g} / \mathrm{g}$ for those irrigated by the well and lake water, respectively. The level in corresponding well water was below the method detection limit; however in the Lake Ziway water $0.06 \pm 0.00 \mathrm{mg} / \mathrm{L} \mathrm{Co}$ was obtained.

Cd concentrations obtained by this study were $0.6 \pm 0.07$ and $0.5 \pm 0.06 \mu \mathrm{g} / \mathrm{g}$ in onion bulb irrigated with well and Lake Ziway water, respectively, while the level was $0.01 \pm 0.00 \mathrm{mg} / \mathrm{L}$ in the lake water analyzed. It was found below the method detection limit in the well water sample. The presence of $\mathrm{Cd}$ in the onion bulb is of concern since onion is used daily in many forms. $\mathrm{Cd}$ has not been known to have beneficial effect for plants and animals, indeed long term human exposure causes kidney damage and ultimately failure and being carcinogenic. Normal intake of $\mathrm{Cd}$ is $1-3 \mu \mathrm{g}$ per day.

$\mathrm{Pb}$ concentration in both onion and irrigation water samples were below the method detection limit. Therefore the results from obtained by the study concerning $\mathrm{Pb}$ is in accordance with the health requirement.

\section{Comparisons of metal levels between water and onion bulbs}

Besides, metals are persistent in the environment and tend to bioaccumulate in plants and organisms, even becoming biomagnified in the food chain to the top where human beings are highly exposed $[16,28]$. Bioaccumulation is of course a normal and essential process enabling the organism to have reserve for latter use for metalloproteins or cofactors or protect themselves against toxic effects. As in most plants and living organisms, higher concentrations were observed in onion bulb compared with that of irrigation waters of both lake and well (Table 4 and 5). 
Comparison of metal levels in onion bulbs with literature values

The levels of major metals $(\mathrm{Ca}, \mathrm{Mg}, \mathrm{Na}$, and $\mathrm{K}$ ) in onion bulbs have been reported in different countries from different points of views (nutritional, health problems, crop yield, etc). Some of the available data are presented in Table 6A along with the data of this study for comparison.

Table 6A. Comparison of levels of major metal levels reported in onion worldwide (all values are in $\mathrm{mg} / 100 \mathrm{~g}$ ).

\begin{tabular}{|c|c|c|c|c|c|c|}
\hline \multicolumn{2}{|l|}{ Country } & $\mathrm{Ca}$ & $\mathrm{Mg}$ & $\mathrm{Na}$ & $\mathrm{K}$ & Ref. \\
\hline \multicolumn{2}{|l|}{ Spain } & $14.8 \pm 0.8$ & $9.28 \pm 0.64$ & $2.32 \pm 0.50$ & $190 \pm 17$ & {$[23]$} \\
\hline \multicolumn{2}{|l|}{$\mathrm{UAE}^{*}$} & $8.4(4.59)$ & $\begin{array}{c}24.1 \\
(2.15) \\
\end{array}$ & $\begin{array}{c}1511.3 \\
(2.23) \\
\end{array}$ & $\begin{array}{c}8642.2 \\
(2.19) \\
\end{array}$ & {$[22]$} \\
\hline \multicolumn{2}{|c|}{ Saudi Arabia } & 84.9 & 22.8 & 3.19 & 26.9 & \multirow[t]{4}{*}[16,28]{} \\
\hline \multicolumn{2}{|c|}{ U.S.A. } & 19 & 9.2 & 3.3 & 143 & \\
\hline \multicolumn{2}{|c|}{ Denmark conventional } & $19.7 \pm 8.41$ & $10.2 \pm 1.69$ & $21.4 \pm 11.1$ & $164 \pm 93.5$ & \\
\hline \multicolumn{2}{|c|}{ Denmark organic } & $14.2 \pm 5.56$ & $10.9 \pm 1.82$ & $15.9 \pm 5.44$ & $183 \pm 118$ & \\
\hline \multirow[b]{2}{*}{ Ethiopia } & Irrigated with well water & $59.9 \pm 3.0$ & $51.6 \pm 1.2$ & $20.8 \pm 0.5$ & $313 \pm 4$ & \multirow[t]{2}{*}{ This study } \\
\hline & Irrigated with Lake Ziway water & $55.0 \pm 2.0$ & $40.7 \pm 3.0$ & $12.1 \pm 0.3$ & $330 \pm 5$ & \\
\hline
\end{tabular}

*Values in parenthesis are relative standard deviations.

The mean levels of $\mathrm{Na}$ and $\mathrm{K}$ in onion bulbs of this study were higher than those reported by Mendez et al. [23] and the results from Saudi Arabia and U.S.A. [16, 28]. However Khan et al. [22] have reported $\mathrm{K}$ and $\mathrm{Na}$ as high as 86422 and $15113 \mathrm{mg} / \mathrm{kg}$, respectively. The levels of $\mathrm{Na}$ were similar to those studied in Denmark but higher than those in Saudi Arabia and U.S.A. [16, 28]. The amounts of $\mathrm{Ca}$ and $\mathrm{Mg}$ in onion bulb of present study were higher than that obtained by Mendez et al. [23] and Khan et al. [22]. Calcium was however lower than that of Saudi Arabia [16, 28].

Comparison of levels of trace metals in onion vegetable reported in various parts of the world are summarized in Table 6B.

Table 6B. Comparison of levels of trace metals in onion vegetables worldwide (all values in $\mu \mathrm{g} / \mathrm{g}$ ).

\begin{tabular}{|c|c|c|c|c|c|c|c|c|c|}
\hline \multicolumn{2}{|l|}{ Country } & $\mathrm{Zn}$ & $\mathrm{Mn}$ & $\mathrm{Cu}$ & $\mathrm{Cr}$ & Co & $\mathrm{Cd}$ & $\mathrm{Pb}$ & Ref. \\
\hline \multicolumn{2}{|l|}{ Nigeria } & $2.00-4.55$ & $1.00-6.6$ & $0.34-1.00$ & $3.00-7.1$ & $\begin{array}{c}0.03-0 . \\
22\end{array}$ & $\begin{array}{c}0.22-0.8 \\
9 \\
\end{array}$ & $2.00-9.5$ & {$[1,13,17]$} \\
\hline \multicolumn{2}{|c|}{ Pakistan $^{\mathrm{a}}$} & $3.4-8.33$ & $1.9 \pm 0.01$ & $0.8 \pm 0.00$ & $1.1 \pm 0.00$ & - & - & - & {$[21]$} \\
\hline \multicolumn{2}{|c|}{ China, Shanghai } & 3.280 & - & 0.900 & 0.070 & - & - & 0.040 & [19] \\
\hline \multicolumn{2}{|c|}{ Chile } & $31 \pm 8$ & - & $7.7 \pm 1$ & - & - & - & - & {$[20]$} \\
\hline \multicolumn{2}{|l|}{$\mathrm{UAE}^{\mathrm{b}}$} & - & $76(2.58)$ & $0.10-1.6$ & $4.2(0.71)$ & - & $\begin{array}{c}0.06 \\
(8.00) \\
\end{array}$ & $\begin{array}{c}0.24 \\
(9.52) \\
\end{array}$ & [22] \\
\hline \multicolumn{2}{|c|}{ Ethiopia (onion leaves) } & 15.4 & - & 5.24 & 2.81 & - & 0.018 & - & [29] \\
\hline \multicolumn{2}{|c|}{ Korea } & $256 \pm 79.5$ & - & $26.4 \pm 4.58$ & - & - & $\begin{array}{c}1.88 \pm 0.3 \\
5\end{array}$ & $\begin{array}{c}4.23 \pm 1.1 \\
6 \\
\end{array}$ & [15] \\
\hline \multicolumn{2}{|l|}{ Poland } & $10.9 \pm 3.5$ & - & $3.47 \pm 1.24$ & - & - & \begin{tabular}{|c|}
$0.04 \pm 0.0$ \\
2 \\
\end{tabular} & $\begin{array}{c}0.45 \pm 0.6 \\
9 \\
\end{array}$ & [30] \\
\hline \multicolumn{2}{|l|}{ Spain } & $1.72 \pm 0.13$ & $0.75 \pm 0.09$ & $0.33 \pm 0.01$ & - & - & - & - & [23] \\
\hline \multirow[t]{2}{*}{ Ethiopia } & $\begin{array}{l}\text { Onion } \\
\text { irrigated with } \\
\text { well water }\end{array}$ & $18.0 \pm 0.7$ & $8.8 \pm 0.2$ & $3.2 \pm 0.1$ & $4.9 \pm 0.2$ & $1.2 \pm 0.5$ & $0.6 \pm 0.07$ & $<0.5$ & \multirow[t]{2}{*}{ This study } \\
\hline & $\begin{array}{l}\text { Onion } \\
\text { irrigated with } \\
\text { lake water } \\
\end{array}$ & $14.1 \pm 0.4$ & $13 \pm 1$ & $3.6 \pm 0.2$ & $6.6 \pm 0.1$ & $1.8 \pm 0.1$ & $0.5 \pm 0.06$ & $<0.5$ & \\
\hline
\end{tabular}

${ }^{\mathrm{a}}$ mean $\pm 2 \mathrm{SD}$ at $99 \% \mathrm{CL}$ in onion bulb. ${ }^{\mathrm{b}}$ value in parenthesis are \% relative standard deviation. 
The mean concentration of $\mathrm{Zn}$ in the onion bulb of the study area, $18 \mathrm{mg} / \mathrm{kg}$ and $14 \mathrm{mg} / \mathrm{kg}$ for those irrigated with well and lake water, respectively, were highest among trace metals but comparable with $18.3 \mathrm{mg} / \mathrm{kg}$ mean $\mathrm{Zn}$ content of edible part of onion set by USDA and $100-400 \mathrm{mg} / \mathrm{kg}$ phytotoxic range [13]. However, the concentrations were higher than FAO/WHO limit of $0.3 \mathrm{mg} / \mathrm{kg}$ and even the more constraint WHO/EU limit of $0.2 \mathrm{mg} / \mathrm{kg}$ in vegetables [13]). The levels of $\mathrm{Zn}$ were also higher than literature reports of Hashmi et al. [21], Akan et al. [17], Abdullahi et al. [13], Iyaka [1], Zhou et al. [19] and Mendez et al. [23]. Much higher concentrations of $\mathrm{Zn}(256 \pm 79.5 \mathrm{mg} / \mathrm{kg})$ were however reported by Jung [15] and 31 $\mathrm{mg} / \mathrm{kg}$ by Badilla-Ohlbaum et al. [20]. In addition the levels of $\mathrm{Zn}$ were below the $20 \mathrm{mg} / \mathrm{kg}$, $99.4 \mathrm{mg} / \mathrm{kg}$ and 0-400 mg/kg limit of MAFF, Codex Alimentarius Commision, and phytotoxic range, respectively [13]. The recommended daily allowance of $\mathrm{Zn}$ is $12-15 \mathrm{mg}$ for an adult person. Societies in which meat is not a major component of their foods are particularly found to practice as low intake as $5 \mathrm{mg} / \mathrm{day}$. The onion bulb in the study area therefore can be used as a good dietary source of $\mathrm{Zn}$. Ingestion of 75-300 mg/day in the form of dietary supplements has been shown to interfere with absorption of $\mathrm{Cu}, \mathrm{Fe}$ and other trace metals while $1 \mathrm{~g}$ zinc salt ingestion causes irritation of intestine, nausea and abdominal pain [16, 28].

The average Mn composition of onion bulbs in the study area, $8.8 \mathrm{mg} / \mathrm{kg}$ and $13 \mathrm{mg} / \mathrm{kg}$ dry wt. for those watered with well and Lake Ziway, respectively, were found to be above $0.2 \mathrm{mg} / \mathrm{kg}$ WHO/EU limit for vegetables [13], and the $1.9 \mathrm{mg} / \mathrm{kg}$ reported by Hashmi et al. [21]. Mn concentration as high as $76 \mathrm{mg} / \mathrm{kg}$ has been reported however by Khan et al. [22]. Mn is so important in brain and bone development and safe and adequate daily intake of $2-3 \mathrm{mg}$ for an adult is recommended [16, 28].

$\mathrm{Cu}$ concentration in onion bulbs determined in this study was less than 7.7 and $15 \mathrm{mg} / \mathrm{kg}$ for onion and tomato, respectively, reported by Badilla-Ohlbaum et al. [20]. The level was also below the values reported for onion leaves samples in the range of $6.917-9.833 \mathrm{mg} / \mathrm{kg}$ by Abdullahi et al. [13]. Cu concentration as high as $26.4 \mathrm{mg} / \mathrm{kg}$ was also found by Jung [15] in samples taken in the vicinity of $\mathrm{Cu}-\mathrm{W}$ mine. The present level attained were however higher than 0.8 and $1.6 \mathrm{mg} / \mathrm{kg}$ reported by Iyaka [1], $0.8 \mathrm{mg} / \mathrm{kg}$ by Hashmi et al. [21] and $0.10 \mathrm{mg} / \mathrm{kg}$ Khan et al. [22]. The concentrations of this study were comparable with that of $3.47 \mathrm{mg} / \mathrm{kg}$ reported by Mocko [30]. Furthermore the present result in onion bulb cultivated with both the well and lake water were below the standards of USDA nutrient data base mean $\mathrm{Cu}$ content of edible onion part [29], maximum tolerable content in vegetables, FAO/WHO joint limit (5.0 $\mathrm{mg} / \mathrm{kg}$ ) and phytotoxic range of $20-100 \mathrm{mg} / \mathrm{kg}$ [13]. The safe and adequate intake of $\mathrm{Cu}$ for adult person is estimated to be $1.5-3.0 \mathrm{mg}[16,28]$. The onion bulb in the study area can therefore be a safe and good dietary source of $\mathrm{Cu}$ for consumers.

Cr levels in edible part of onion in the study area were 4.9 and $6.6 \mathrm{mg} / \mathrm{kg}$ in the vegetable irrigated with well and lake water and were within the range of $3.0-7.1 \mathrm{mg} / \mathrm{kg}$ determined in Nigeria [1, 13, 17] and 3.87-8.87 mg/kg estimated by Abdullahi et al. [18]. The levels were however higher than reported values of 1.1 [21], 0.070 [19] and $4.2 \mathrm{mg} / \mathrm{kg}$ [22]. In addition it exceeded the $2.30 \mathrm{mg} / \mathrm{kg}$ maximum load of vegetables (Codex, 2001) and $0.1-0.2 \mathrm{mg} / \mathrm{kg}$ FAO/WHO joint limit [17]. The levels were below toxic stage for human, $200 \mathrm{mg} / \mathrm{kg}$ [13]. Trivalent chromium is essential in glucose tolerance factor with safe and adequate daily intake of $0.05-0.02 \mathrm{mg} /$ adult $[16,28]$. Trivalent chromium is known to exist in soil usually largely as insoluble and unavailable compounds which might indicate that the high level in the onion bulb might be from contamination of ground water and Lake Ziway with municipal and industrial wastes of tannery, pigments, steel and others, disposed in to tributary rivers (Meki River and Katar River) as well as Mojo River or to soils.

Co levels obtained in this study in onion bulbs irrigated with well and lake water were 1.2 and $1.8 \mathrm{mg} / \mathrm{kg}$, respectively. Assessing literatures data on Co level of vegetables particularly 
onion is few, however one recent study conducted in Nigeria by Akan and his coworkers [17] found $\mathrm{Co}$ in onion in the range of $0.03-0.22 \mathrm{mg} / \mathrm{kg}$ which was much lower than the values estimated in this study. Co exists as a component of vitamin $\mathrm{B}_{12}$, cobalamin whose deficiency if occurred causes pernicious anemia in human being. The recommended dietary allowance of cobalt is $0.002 \mathrm{mg}$ /adult as vitamin $\mathrm{B}_{12}[16,28]$.

$\mathrm{Cd}$ triggers the need for concern in the study area which were 0.6 and $0.5 \mathrm{mg} / \mathrm{kg}$ for the onion bulb grown with water from well and water diverted from Lake Ziway through furrow irrigation, respectively. These levels were much higher than the $0.018 \mathrm{mg} / \mathrm{kg}$ of onion leaf content estimated earlier by Itanna [29] in farmlands fed with effluents from Akaki Textile Factory as well as 0.06 [22], and $0.04 \mathrm{mg} / \mathrm{kg}$ [30]. However the values in this study were lower than the $0.8-1.00 \mathrm{mg} / \mathrm{kg}$ [18] and $1.8 \mathrm{mg} / \mathrm{kg}$ [15] reported in the literature. Values in the range of $0.05-0.43 \mathrm{mg} / \mathrm{kg}$ [18] were also mentioned in the literature. Generally, the levels determined in this study were above the WHO/FAO limit $(0.02-0.2 \mathrm{mg} / \mathrm{kg}), \mathrm{WHO} / \mathrm{EU}$ limit $(0.01 \mathrm{mg} / \mathrm{kg})$, and MAFF (0-1 mg/kg) [18] but did not reach phytotoxic level estimated phototoxic range of $1-30 \mathrm{mg} / \mathrm{kg}$ [18].

The results of this study showed $\mathrm{Pb}$ content of the onion bulb were below the method detection limit that assures the low $\mathrm{Pb}$ exposure of the farm fields as well as waters in the study area. However in the literatures values as high as 4.23 [15], 0.24 [22], and 6-13.00 $\mathrm{mg} / \mathrm{kg}$ [18] were reported in onion vegetables.

\section{Comparison of metals in irrigation water with literature values and guidelines}

The concentration of Co and Cd of Lake Ziway sample in this study was comparable with that of Nigussie et al. [31] in the lake area, however $\mathrm{Cr}$ was much higher while $\mathrm{Cu}$ was lower in this study (Table 7). Compared with the Bellandur Lake in India, levels of $\mathrm{Cu}, \mathrm{Zn}$ and $\mathrm{Pb}$ in Lake Ziway were lower while that of $\mathrm{Cr}$ and $\mathrm{Cd}$ were higher in this study. The $\mathrm{Cu}$ and $\mathrm{Zn}$ determined in surface water of Nigeria seems to be much concentrated in the metals than that of the ground water and lake water in the present study.

Table 7. Comparison of trace metal concentrations in water reported in the literature.

\begin{tabular}{|c|c|c|c|c|c|c|c|c|c|c|c|}
\hline Country & Water type & $\mathrm{Cu}$ & $\mathrm{Zn}$ & $\mathrm{Cr}$ & $\mathrm{Ni}$ & $\mathrm{Fe}$ & $\mathrm{Mn}$ & $\mathrm{Co}$ & $\mathrm{Cd}$ & $\mathrm{Pb}$ & Ref. \\
\hline Nigeria & $\begin{array}{c}\text { Borehole, } \\
\text { hand dug, } \\
\text { surface } \\
\text { water } \\
\end{array}$ & $\begin{array}{c}0.12- \\
0.34\end{array}$ & $\begin{array}{c}0.12- \\
0.16\end{array}$ & & $\begin{array}{c}0.15- \\
0.28\end{array}$ & $\begin{array}{c}0.32- \\
0.67\end{array}$ & & & & & [32] \\
\hline India & $\begin{array}{c}\text { Bellandur } \\
\text { lake (dry } \\
\text { season) }\end{array}$ & 0.016 & 0.113 & 0.005 & 0.0065 & 0.777 & & & 0.0033 & 0.006 & [9] \\
\hline Ethiopia & $\begin{array}{c}\text { Lake } \\
\text { Zeway }\end{array}$ & $\begin{array}{c}0.03- \\
0.04 \\
\end{array}$ & & 0.06 & & & & $\begin{array}{l}0.05- \\
0.064\end{array}$ & $\begin{array}{c}0.009- \\
0.01\end{array}$ & & [31] \\
\hline \multirow[t]{2}{*}{ Ethiopia } & Well & $<0.2$ & $\begin{array}{l}0.04 \pm \\
0.004\end{array}$ & $\begin{array}{c}0.44 \\
\pm 0.01\end{array}$ & - & - & $\begin{array}{c}1.1 \\
\pm 0.01\end{array}$ & $<0.01$ & $<0.007$ & $<0.1$ & \multirow[t]{2}{*}{$\begin{array}{l}\text { This } \\
\text { study }\end{array}$} \\
\hline & $\begin{array}{c}\text { Lake } \\
\text { Zeway }\end{array}$ & $<0.2$ & $\begin{array}{l}0.08 \pm \\
0.004\end{array}$ & $\begin{array}{c}0.42 \\
\pm 0.02 \\
\end{array}$ & - & - & $\begin{array}{l}0.05 \pm \\
0.005\end{array}$ & $\begin{array}{c}0.06 \pm \\
0.002 \\
\end{array}$ & $\begin{array}{c}0.01 \pm \\
0.001 \\
\end{array}$ & $<0.1$ & \\
\hline
\end{tabular}

Table 8. Some guidelines for water quality (all units $\mathrm{mg} / \mathrm{L}$ ).

\begin{tabular}{|l|c|c|c|c|c|c|c|c|c|c|}
\hline Standard & $\mathrm{Cu}$ & $\mathrm{Zn}$ & $\mathrm{Cr}$ & $\mathrm{Ni}$ & $\mathrm{Fe}$ & $\mathrm{Mn}$ & $\mathrm{Co}$ & $\mathrm{Cd}$ & $\mathrm{Pb}$ & $\mathrm{Ref}$ \\
\hline Australia & 0.2 & 2 & 1 & 0.2 & & 2 & & 0.01 & 0.2 & {$[33]$} \\
\hline NEQS Pakistan & & 5 & & 1 & 2 & 1.5 & & 0.1 & 0.5 & {$[33]$} \\
\hline WHO water standard for drinking MCL & 1.3 & 15 & 0.1 & 0.02 & 0.3 & 0.5 & 0.001 & & 0.015 & {$[32]$} \\
\hline
\end{tabular}

Bull. Chem. Soc. Ethiop. 2012, 26(1) 
The level of $\mathrm{Cu}, \mathrm{Zn}, \mathrm{Cr}, \mathrm{Mn}, \mathrm{Pb}$ and $\mathrm{Cd}$ obtained in the irrigation water samples of this study were all below the standards set in Australia and Pakistan (Table 8). However, compared with surface water quality for drinking water set by WHO for $\mathrm{Cr}$ and $\mathrm{Mn}$, in both lake and well water and $\mathrm{Co}$ in lake water exceeds the limit. $\mathrm{Cu}$ and $\mathrm{Zn}$ were below the WHO limit set. Besides compared with EPA for fresh water quality [14], which sets a limit for $\mathrm{Cd}$ chronic $(0.0005$ $\mathrm{mg} / \mathrm{L})$ and acute case $(0.00145 \mathrm{mg} / \mathrm{L})$ indicated that Lake Ziway with mean $0.01 \mathrm{mg} / \mathrm{L} \mathrm{Cd}$ has surpassed the acute case and so should not be used for drinking water unless pretreated. Cr from this study also needs critical consideration particularly on usage of the ground water which also used in the study area for drinking besides irrigation has exceeded the level for chronic case $(0.1$ $\mathrm{mg} / \mathrm{L} \mathrm{Cr}^{3+}$ and $0.011 \mathrm{mg} / \mathrm{L} \mathrm{Cr}^{6+}$ for drinking). The lake water total $\mathrm{Cr}$ level in this study indicated that $\mathrm{Cr}$ exceeded the EPA acute level of $0.0016 \mathrm{mg} / \mathrm{L}$ for $\mathrm{Cr}^{6+}$ while it was far below the acute level of $0.842 \mathrm{mg} / \mathrm{L}$ for $\mathrm{Cr}^{3+}$. Therefore further speciation analysis on the two chromium state especially the hexavalent needs to be done urgently in the water. The water in the study area can be said to be suitable for irrigation of plants however.

Analysis of variance (ANOVA)

Variations in the mean levels of metals between the samples were tested whether it was from just a random error or treatment (i.e. difference in mineral contents of soil, water, atmosphere; variation in application of agrochemicals like fertilizers, pesticides, herbicides, etc or other variations in cultivation procedures) using one way analysis of variance (ANOVA).

Significant differences were obtained $(\mathrm{p}<0.05)$ at $95 \%$ confidence levels for $\mathrm{Ca}, \mathrm{Cu}, \mathrm{Co}$ and $\mathrm{Cr}$ in onion bulbs irrigated with well and Lake Ziway water. However, the variations for $\mathrm{Na}$, $\mathrm{K}, \mathrm{Mg}, \mathrm{Zn}$ and $\mathrm{Cd}$ were not significant $(\mathrm{p}>0.05)$ in the two samples. For the irrigation water samples, except $\mathrm{Ca}$ and $\mathrm{Mg}$ all other metals ( $\mathrm{Na}, \mathrm{K}, \mathrm{Cr}, \mathrm{Mn}$ and $\mathrm{Zn}$ ) do not differ significantly $(\mathrm{p}>0.05)$.

\section{CONCLUSIONS}

Moderate onion consumption contributes for the daily nutritional requirements of many essential metals, including major $(\mathrm{Na}, \mathrm{K}, \mathrm{Ca}$ and $\mathrm{Mg}$ ) and trace metals $(\mathrm{Cu}, \mathrm{Co}, \mathrm{Cr}, \mathrm{Mn}$, and $\mathrm{Zn}$ ). The toxic metal $\mathrm{Pb}$ was not detected in the onion bulbs and irrigation waters revealing that the Ethiopian onions from Meki Town contain either very low concentration $(<0.5 \mathrm{mg} / \mathrm{kg})$ of $\mathrm{Pb}$ or may be free from this metal. However the other toxic metal $\mathrm{Cd}$ in the Meki onions were found to be 0.6 and $0.5 \mathrm{mg} / \mathrm{kg}$ for the onion bulb grown with water from well and water from Lake Ziway, respectively. The values in this study are within the range reported in the literature. However the levels determined in this study are above the WHO/FAO limit $(0.02-0.2 \mathrm{mg} / \mathrm{kg})$ and WHO/EU limit $(0.01 \mathrm{mg} / \mathrm{kg})$ but did not reach phytotoxic level range of $1-30 \mathrm{mg} / \mathrm{kg}$ [18]. In general the levels of major and trace metals found in the Ethiopian onions are comparable with previously reported data on onions from other origin.

\section{ACKNOWLEDGEMENTS}

The authors express their gratitude to the Department of Chemistry, Addis Ababa University, Ethiopia, for providing the laboratory facilities. Reta Birhanu Kitata is thankful to Department of Chemistry, Wolaita Sodo University, Ethiopia, for sponsoring his study.

\section{REFERENCES}

1. Iyaka, Y.A. Electronic J. Environ. Agric. Food Chem. 2007, 6, 2150.

2. Taiga, A.; Suleiman, M.N.; Aina, D.O.; Sule, W.F.; Alege, G.O. Afr. J. Biotechnol. 2008, 7, 1588. 
3. Margen, S. Onions, The Wellness Encyclopedia of Food and Nutrition, REBUS: New York; 1992.

4. Central Statistical Agency (CSA), The Federal Democratic Republic of Ethiopia, Agricultural Sample Survey: Area and Production Crops for 2007/2008. Statistical Bulletin Vol. I (417), 2008.

5. W/Tsadik, K.; Sendek, F.; Tefera, H. East Afr. J. Sci. 2008, 2, 130.

6. Gedamu, F. The effect of alternative sources of organic fertlizers in increasing the yield of onions (Allium cepa L.), M.Sc. Thesis, Addis Ababa University, Ethiopia, 1982.

7. Bloem, E.; Haneklaus, H.; Schnug, E. J. Plant Nutr. 2004, 27, 1827.

8. Tokalioglu, S.; Kartal, S.; Gultekin, A. Int. J. Environ. Anal. Chem. 2006, 86, 417.

9. Lokeshwari, H.; Chandrappa, G.T. Curr. Sci. 2006, 91, 622.

10. Bell, F.G. Geological Hazards: Their Assessment, Avoidance and Mitigation, Taylor and Francis: London; 1999.

11. Dima, G.; Popescu, I.V.; Stihi, C.; Oros, C.; Dinu, S.; Manea, L.; Vlacicu, G. Romanian J. Phys. 2006, 51, 667.

12. Adeyeye, E.I. Bull. Chem. Soc. Ethiop. 2005, 19, 175.

13. Abdullahi, M.S.; Uzairu, A.; Okunola, O.J. Afr. J. Biotechnol. 2008, 7, 1526.

14. Olajire, A.A.; Ayodele, E.T. Bull. Chem. Soc. Ethiop. 2003, 17, 11.

15. Jung, M.C. Sensors 2008, 8, 2413.

16. Nabrzyski, M. Mineral Components in Foods in Chemical and Functional Properties of Food Components Sereies, Szefer, P.; Nriagu, J.O. (Eds.), CRC Press: Boca Raton; 2006.

17. Akan, J.C.; Abdulrahman, F.I.; Ogugbuaja V.O.; Ayodele J.T. Am. J. Appl. Sci. 2009, 6, 534.

18. Abdullahi, M.S.; Uzairu, A.; Harrizon, G.F.; Balarabe, M.L. Int. J. Environ. Resour. 2007, $6,1869$.

19. Zhou, Z.; Fan, Y.; Wang, M. Food Rev. Int. 2000, 16, 239.

20. Badilla-Ohlbaum, R.; Ginocchio, R.; Rodriguez, P.H.; Cespedes, A.; Gonzalez, S.; Allen, H.E. Environ. Toxicol. Chem. 2001, 20, 2749.

21. Hashmi, D.R.; Ismail, S.; Shaikh, G.H. Pak. J. Bot. 2007, 39, 747.

22. Khan, S.A.; Ahmad, I.; Mohajir, M.S. Pak. J. Pharm. Sci. 2006, 19, 141.

23. Mendez, C.V.; Rodri-Guez, E.M.; Romero, C.D.; Gonza-Lez, M.G.; Isasa, M.T. Int. J. Food Sci. Nutr. 2007, 1.

24. Rouessac, F.; Rouessac, A. (Eds.) Chemical Analysis: Modern Instrumental Methods and Techniques, Wiley: Chichester; 2000.

25. Ewing, G.W. Instrumental Methods of Chemical Analysis, 5th ed., McGraw-Hill: New York, 1985.

26. Bertini, I.; Gray, H.B.; Lippard, S.J.; Valentine, J.S. Bioinorganic Chemistry, Viva Books: New Delhi; 1998.

27. Perk, M.Vd. Soil and Water Contamination: from molecular to catchment scale, Taylor and Francis: London; 2006.

28. Reilly, C. Mineral Components in Foods in Chemical and Functional Properties of Food Components Sereies, Szefer, P.; Nriagu, J.O. (Eds.), CRC Press: Boca Raton; 2006.

29. Itanna, F. SINET: Ethiop. J. Sci. 1998, 21, 133.

30. Mocko, A.; Wacławek, W. Anal. Bioanal. Chem. 2004, 380, 813.

31. Nigussie, K.; Chandravanshi, B.S.; Wondimu, T. Int. J. Biol. Chem. Sci. 2010, 4, 1641.

32. Jatau, B.S.; Bajeh, I.; Innocent, S. Res. J. Appl. Sci. 2008, 3, 81.

33. Nassef, M.; Hannigan, R.; Sayed, K.A.; Tahawy, M.S. Proceedings of the $2^{\text {nd }}$ Environmental Physics Conference, Alexandria, Egypt, 18-22 Feb. 2006. 